\title{
Business contributions to the sustainable development goals through community sustainability partnerships
}

\author{
Eduardo Ordonez-Ponce \\ Faculty of Business, Athabasca University, Athabasca, Canada \\ Amelia Clarke \\ Faculty of Environment, School of Environment, Enterprise and Development, \\ University of Waterloo, Waterloo, Canada, and \\ Adriane MacDonald \\ Dhillon School of Business, University of Lethbridge, Lethbridge, Canada
}

\begin{abstract}
Purpose - This study aims to understand how businesses can contribute to the achievement of the UN sustainable development goals (SDGs) by implementing Local Agenda 21 (or equivalent) plans in partnership with other organizations situated in their city. To this end, the present study examines drivers and outcomes from the perspective of business partners, as well as their relationships to the SDGs.

Design/methodology/approach - Through a mixed-methods approach this research studies 71 businesses from four large cross-sector partnerships formed to achieve local sustainability goals. Data were collected through a survey to determine why firms partner and what outcomes they obtain from partnering. Qualitative content analyses are used to determine the relationships between business drivers and outcomes from partnering for local sustainability and the SDGs.

Findings - From a resource-based view (RBV) perspective, findings show the value of local sustainability partnerships in relation to the SDGs. Many SDG targets are aligned with the top reasons why businesses join large community sustainability partnerships. Also, through the outcomes achieved by participating in the partnership businesses can further the SDGs.

Research limitations/implications - This research contributes to the literature and to practice through the understanding of businesses partnering for local sustainability, and its relationships to global sustainability. Firstly, the connections of business partners to local and global sustainability are better understood. Of note is the contribution made to the literature on sustainability-related drivers and outcomes expanding and refining RBV literature. Secondly, a positive connection has been established between
\end{abstract}

(C) Eduardo Ordonez-Ponce, Amelia Clarke and Adriane MacDonald. Published by Emerald Publishing Limited. This article is published under the Creative Commons Attribution (CC BY 4.0) licence. Anyone may reproduce, distribute, translate and create derivative works of this article (for both commercial and non-commercial purposes), subject to full attribution to the original publication and authors. The full terms of this licence may be seen at http://creativecommons.org/licences/by/4.0/ legalcode

The author would like to acknowledge the contributions made by the reviewers and editors in the improvement of this article.

Funding: This work was supported by the Social Sciences and Humanities Research Council of Canada (Grant Number 435-2014-1250); Mitacs (Ref Number IT06408); ICLEI Canada; and the University of Waterloo.

Sustainable development goals

Received 6 March 2020 Revised 26 August 2020 26 November 2020 Accepted 30 November 2020 
SAMPJ

12,6

businesses and the SDGs, proposing a virtuous model of relationship that summarizes the findings from this research. And thirdly, large cross-sector social partnerships are better understood.

Practical implications - Small- and medium-sized enterprises and large corporations with local offices can further both local and global sustainable development by engaging in local cross-sector sustainability partnerships.

Social implications - These research findings are crucial for those leading sustainability initiatives, so they can engage businesses actively in light of the important role they play in society improving their contributions and the chances for sustainability partnerships to achieve their goals.

Originality/value - This research contributes to the scale conversation by exploring community sustainability partnerships as a means to understand how business engagement in sustainability at the local level can contribute to the achievement of the SDGs and, ultimately, to global sustainability.

Keywords Business, Outcomes, RBV, Collaboration, Human resources, Drivers, SDGs, Cross-sector partnerships, Sustainable cities, Organizational resources, Large partnerships, Sustainability resources

Paper type Research paper

\section{Introduction}

The sustainable development goals (SDGs) have been called the broadest accord ever accomplished on social and environmental challenges (George et al., 2016), representing a shared vision for a just, safe and sustainable future for humanity (United Nations Development Programme, 2020). As part of the United Nations 2030 Agenda, the SDGs were designed to guide sustainability decisions, influence politics and leverage financial resources to address poverty, environmental protection, social inclusion and economic growth (Gusmão Caiado et al., 2018). The SDGs are global in impact and all countries and sectors are responsible for their accomplishment (Osborn et al., 2015), including public, civil society and private sector organizations (Sachs, 2012). Nevertheless, despite its good intentions, the SDGs require major changes by every country (Schmidt-Traub et al., 2017), as well as huge efforts for measuring and monitoring progress (Swain, 2018). Furthermore, the SDGs seem to be weak on agency, with few obligations for governments and zero for businesses or consumers (Spangenberg, 2017). The corporate sector provided great support to the development of the SDGs (Shrivastava, 2018); it was a relevant partner to the United Nations in its design (Scheyvens et al., 2016). Currently, many multinational corporations have started reporting on and communicating about the relevance of their operations to the SDGs (ElAlfy et al., 2020).

Businesses have progressively united organizations from different sectors to tackle sustainability challenges (George et al., 2016), playing a critical role in achieving the SDGs (Rosati and Faria, 2019; Scheyvens et al., 2016). The private sector has access to leading-edge technologies, worldwide reach and the capability to develop solutions at a large scale, all vital features to achieve global sustainability goals (Sachs, 2012). Businesses are possibly the most powerful organization on Earth (Davis and Marquis, 2005; Googins and Rochlin, 2000), and have become "an increasingly dominant social institution", getting engaged in economic matters, as well as in environmental and social issues (Bakan, 2004; Crane and Seitanidi, 2014, p. 3). By partnering for sustainability, they can move beyond business-as-usual (Leisinger, 2015) towards assuming a public commitment to improve society (Loza, 2004). The SDGs represent a potential opportunity to return to their fundamental responsibility and role in society, not only through principles of morality, markets and basic institutions as suggested by Hsieh (2017) but also by means of relational practices (Laasonen et al., 2012) and in positive collaboration with all sectors of society (Mintzberg, 2015). That said, progress towards the SDGs has been slow (United Nations, 2019) and local businesses are poorly engaged (Verboven and Vanherck, 2016).

Cities are where "the battle for sustainable development will be won - or lost" (Eliasson, 2015, p. 1), endorsing the need for sustainability plans at local levels "in every area in which 
human impacts on the environment" (UN-DESA, 2015, p. 1). This rationale was part of the discussion surrounding Agenda 21 at the Earth Summit in Rio de Janeiro in 1992, a comprehensive plan of action for sustainable development at all levels (United Nations, 1992). Under this context, Local Agenda 21 (LA21) was proposed as "a participatory, multisectoral process to achieve the goals of Agenda 21 at the local level through the preparation and implementation of a long-term, a strategic action plan that addresses priority local sustainable development concerns" (ICLEI, 1997, para. II). As local governments do not always have the necessary resources or role to implement LA21s, collaborative approaches become relevant to promote common sustainability interests among stakeholders, as an adequate context for the implementation of local sustainability agendas (Barrutia et al., 2007). LA21 seeks to integrate environmental and development concerns for fulfilling basic needs, improving living standards and protecting and managing ecosystems towards a safer and more prosperous future (United Nations, 1992). These challenges are aligned with the current SDGs, urging local governments to "dialogue with citizens, local organizations and private enterprises" (United Nations, 1992, para. 28.3). Since 1992, thousands of cities have implemented LA21s or their equivalent to tackle sustainability issues (Moallemi et al., 2019; Rok and Kuhn, 2012), with many of them collaborating with organizations from diverse sectors in the design and implementation of their sustainability strategies (MacDonald et al., 2018). While these partnerships implement sustainability strategies at the local level, they also contribute to the achievement of global sustainability (Griggs $e t$ al., 2013), with public, private and civil society organizations as key actors partnering for the accomplishment of local SDGs (Clarke and MacDonald, 2019)[1].

The pressure on businesses to be socially and environmentally responsible will only increase (Hsieh, 2017; Siltaoja and Onkila, 2013) and sustainability partnerships that tackle local issues present an opportunity to respond to these pressures (Clarke and MacDonald, 2019). Local sustainability partnerships exist in thousands of communities worldwide (Moallemi et al., 2019; Rok and Kuhn, 2012), and as previously highlighted, businesses are essential to realizing the SDGs. Given the challenge of considering scale (Bansal et al., 2018), specifically different spatial sizes (e.g. local, national, global, etc.) (Peterson et al., 1998), this article aims to understand if local sustainability partnerships can offer an opportunity for businesses to attain their organizational goals and, at the same time, contribute to the achievement of the SDGs. Specifically, the empirical research questions being answered are, namely, what drives businesses to join community sustainability partnerships? What outcomes are realized when businesses partner for local sustainability? And do business outcomes from partnering for local sustainability contribute to the achievement of global SDGs?

The present study seeks to answer the aforementioned research questions through a mixed-methods approach. Firstly, a survey on business drivers and outcomes, informed by the resource-based view (RBV) literature, was used to collect data from businesses that are partners in local sustainability partnerships. For reference, drivers are defined as the prospective resources that business partners stand to obtain from partnering for sustainability, whereas outcomes are the actual resources that partners obtain from partnering. Here the term resources are adopted from RBV and refer to any asset or capability that a firm can draw on to bolster its strategic position (Barney, 1991). The purpose of this survey was to determine: what drivers prompt business partners to join this type of partnership (Brinkerhoff, 2002) and what realized outcomes of partnering are valued most by business partners (Clarke and Fuller, 2010). Secondly, content analysis on the SDGs in light of the survey findings was performed. The aim of this qualitative analysis was to determine the degree of overlap that exists between business outcomes from partnering locally and the SDGs. Findings show sustainability, organizational and human drivers and
Sustainable development goals

1241 
SAMPJ

12,6

1242

outcomes as the highest-rated for business with clear connections between them and the SDGs, presenting the SDGs as an opportunity for businesses to move beyond business-asusual and assume commitments with societal challenges. Furthermore, local sustainability partnerships could help businesses gain sustainability, human and organizational resources while enabling local and global sustainability progress. While the findings from this research help sustainability leaders to improve the engagement of businesses in local sustainability partnerships and contribute to the SDGs, these results are also useful for the business community to understand the value of partnering for sustainability.

The article is structured as follows. Following the introduction, literature on business and the SDGs, partnerships for local sustainability and about business' drivers and outcomes for local sustainability is presented. Then, the methods used are explained being followed by the results, which lead to the final sections on discussion and conclusions.

\section{Literature}

This literature review focuses on business and the SDGs with a particular emphasis on sustainability partnerships and business drivers and outcomes.

\section{Business and the sustainable development goals}

On 25th September 2015, 195 countries agreed to 17 SDGs and 169 targets as part of the 2030 Agenda for Sustainable Development (United Nations Development Programme, 2020), a process in which the private sector played a key role (Scheyvens et al., 2016). However, the complexity of sustainable development (Rittel and Webber, 1973) has been a challenge for businesses to integrate into their strategies as they continue to favour short-term smallerscale goals over long-term big picture sustainability (Montiel et al., 2020). Thus, the adoption of the SDGs could allow businesses to orient their activities and strategies using it as a framework towards specific goals (Sullivan et al., 2018).

The SDGs are integrated and indivisible, balancing the economic, environmental and social dimensions of sustainable development (United Nations, 2015a). The SDGs are also interdependent, with governance and global partnerships as key players in their success (Kolk et al., 2017). Whilst SDG\#16 argues that "without peace, stability, human rights and effective governance" sustainable development cannot be accomplished, SDG\#17 proposes that only through "global partnership and cooperation" the SDGs can be achieved (United Nations Development Programme, 2020, p. 1). Similarly, local partnerships are crucial for the sustainable development of cities (Clarke and Ordonez-Ponce, 2017), which as a whole can contribute to the achievement of the SDGs because of the thousands of local sustainability partnerships existing worldwide (Moallemi et al., 2019; Rok and Kuhn, 2012). However, the SDGs are also inconsistent and it is very hard to monitor them (Swain, 2018). Furthermore, their implementation is extremely complex, with what some have called "[un] realistic plans" to achieve them (Spangenberg, 2017, p. 318). For example, while economic growth has a positive effect on social issues such as the reduction of poverty (Spaiser et al., 2017), its increase has been largely considered to be incompatible with reducing our impact on climate and biodiversity (Eboli et al., 2010; Rosales, 2008).

Certainly, achieving the SDGs is a challenge and businesses have a key role to play (Sachs, 2012). While the SDGs can be considered an opportunity for businesses to demonstrate how they can help achieve sustainable development (Ordonez-Ponce and Khare, 2020), by minimizing their negative impacts and maximizing their positive contributions on people and the planet (Jones et al., 2016), they can also be relevant for the development of partnerships and strategic positioning (Sullivan et al., 2018). Moreover, the SDGs have been found to be a useful framework under which businesses can operate and 
use to guide their investments, innovation and decisions (Ordonez-Ponce and Khare, 2020), with the potential of rewarding them with huge economic returns if they deliver goods and services that are needed for the achievement of the SDGs (Hsieh, 2017; Pedersen, 2018). However, for businesses to really get engaged and contribute to the SDGs, business as usual must change (Scheyvens et al., 2016) and not only focus on the SDGs as a business opportunity but also assume their responsibilities to society (Hsieh, 2017; Siltaoja and Onkila, 2013).

\section{Partnerships for community sustainability}

Partnerships are considered to be a key to the achievement of sustainable development (Koontz, 2006), something that local governments have recognized towards the achievement of sustainability goals (Clarke and Fuller, 2010). Partnerships refer to a configuration of stakeholders that collaborate to reach common socio-environmental goals (Glasbergen, 2007), representing a "pluralistic approach" that involves stakeholders who contribute with their strengths towards solving societal needs (Glasbergen, 2007, p. 1). In fact, research shows that more comprehensive forms of collaboration can lead to desirable outcomes (Kalesnikaite, 2019), supporting community-wide plan implementation and goal realization (Alonso and Andrews, 2019). Nevertheless, partnerships demand important investments to be created, developed and persist in time (Googins and Rochlin, 2000; Margerum and Robinson, 2015). Furthermore, some of the challenges faced by partnerships are linked to the diverse goals of the partners, their potentially conflicting views and the lack of collaborative experience (Babiak and Thibault, 2009), all issues that can lead to fail partnerships (Googins and Rochlin, 2000; Margerum and Robinson, 2015).

Businesses form partnerships with public organizations, non-governmental organizations (NGOs) and/or other businesses (Glasbergen, 2007), providing them with an avenue to be socially responsible (Selsky and Parker, 2005). The partnerships that involve public, private and civil society organizations and that focus on economic, social and environmental issues concerning all the partners are called cross-sector social partnerships (CSSPs) (Crane and Seitanidi, 2014; Selsky and Parker, 2005). As expected, due to the global sustainability crisis (Griggs et al., 2013; Steffen et al., 2011, 2015), large CSSPs are becoming increasingly popular (Gray and Stites, 2013; MacDonald et al., 2018). However, research on these partnerships, and in particular, their outcomes is nascent and so understanding of this organizational form and its capacity to realize its goals is still developing (Ordonez-Ponce and Clarke, 2020).

Some of the issues being addressed by CSSPs include education, economic development, energy, climate change, poverty alleviation, unemployment, health, water scarcity, air quality, ecological diversity, waste, corruption, organized crime, safety, transportation and food security (Clarke and Fuller, 2010; Crane and Seitanidi, 2014; MacDonald et al., 2018; Ordonez-Ponce and Clarke, 2020; Selsky and Parker, 2005; Waddock, 1991). A list of local sustainability challenges that strongly matches the global SDGs (MacDonald et al., 2018; Salvia et al., 2019), with some minor exceptions. Local sustainability plans do not currently address gender equality, for example (MacDonald et al., 2018). However, every other SDG has a related topic in local sustainability plans, and some cities are even explicitly linking their plans to the SDGs (City of Kitchener, 2019). By working within local sustainability partnerships, businesses can ensure their sustainability actions are within local and global ecological limits and aligned with science-based targets (Clarke et al., 2019).

Alignment between local and global sustainability goals is a step in the right direction and helps address scale by ensuring local actions can collectively contribute to the global agenda (Goworek et al., 2018; Kythreotis and Jones, 2012). Businesses in particular often
Sustainable development goals

1243 
SAMPJ

12,6

1244

miss the big picture because they are either concentrated on minor details or omit granular understandings, as they are looking at the macro level (Bansal et al., 2018). While limited resources constrain organizational capacity (Rerup, 2009), it is also a reality that businesses still struggle with long-term big picture issues such as climate change or biodiversity loss as they remain constrained by their short-term and smaller-scale goals (Montiel et al., 2020). These constraints and their short-term smaller-scale goals are the ones usually being blamed for our unsustainable state (Flammer and Bansal, 2017) and which if not addressed properly, will make sustainability unreachable (Lee, 1993).

Businesses are crucial in the achievement of sustainability at the local (Clarke et al., 2019; MacDonald et al., 2018) and global levels (Sachs, 2012). However, even though there is research on what drives businesses to join partnerships and on their obtained outcomes from partnering (Gray and Stites, 2013; Selsky and Parker, 2005; Waddock, 1989), little is known about whether the reasons for them to join local sustainability partnerships and what they obtain from it can contribute to the achievement of the SDGs.

\section{Business drivers for sustainability partnering}

Organizations engage in sustainability partnerships for strategic reasons (Eisenhardt and Schoonhoven, 1996; Ordonez-Ponce and Clarke, 2020; Wassmer et al., 2017). Partnering organizations are key actors whose performance decides the success or failure of a partnership (Ansell and Gash, 2008), aiming to obtain specific and tangible benefits (Waddock, 1989), and to achieve collaborative advantages that they could not accomplish alone (Glasbergen, 2007).

A resource perspective is one of the most used views for studying organizational engagement in partnerships (Gray and Stites, 2013; Selsky and Parker, 2005), stating that organizations join partnerships for obtaining resources they need to succeed and survive (Fombrun and Astley, 1983; Penrose, 1959). Consequently, the RBV has been largely used to study organizational drivers to partner (Branzei and Le Ber, 2014).

$\mathrm{RBV}$ is a powerful theory to study competitive advantage and organizational relationships (Barney et al., 2011). This theory argues that businesses are heterogeneous organizations that possess management skills, capital, technical know-how and reputation as resources (Barney, 1991). According to RBV, organizations partner when they are in vulnerable strategic positions so they can gain additional resources that they need because of partnerships or when they are in comfortable positions to attract and engage other organizations (Eisenhardt and Schoonhoven, 1996). RBV clusters resources into four types of capital: human including experience and knowledge; organizational such as relationships, history and trust; physical such as technology, machines and manufacturing facilities; and financial capitals including equity, debt and earnings (Barney, 1995). Nonetheless, traditionally RBV does not identify socio-environmental drivers for organizations to partners (Barney et al., 2011; Hart, 1995) such as those that focus on collective social problems (MacDonald et al., 2019), the challenges and constraints placed by nature on businesses (Barney et al., 2011; Hart, 1995) or society's sustainability (Kolk et al., 2010). While Gray and Stites (2013) identify this type of resources calling them society-oriented, this article uses the term sustainability capital, consistent with the focus of the studied partnerships.

According to the social partnership literature, two main motives drive businesses to partner, namely, a strategic or utilitarian reason or a social or altruistic rationale (Eisenhardt and Schoonhoven, 1996; Vurro et al., 2010). According to the strategic perspective, businesses join partnerships to access new markets and improve their market positions (Googins and Rochlin, 2000), to improve their image, reputation, status and legitimacy (Gray 
and Stites, 2013) or to learn and gain expertise (Kolk et al., 2010). Furthermore, businesses also join partnerships to control human (Kolk et al., 2010), organizational (Lotia and Hardy, 2008), physical (Eisenhardt and Schoonhoven, 1996) and financial resources (Gray and Stites, 2013), to address socio-environmental pressures (Lin and Darnall, 2015) or to improve their strategic positions and gain competitive advantage (Selsky and Parker, 2005). From the social perspective, businesses join partnerships to be more environmentally and socially responsible (Kolk et al., 2010), to address socio-environmental issues (Clarke and Fuller, 2010) or to improve the community's sustainability (Gray and Stites, 2013). However, this dichotomy is not that clear-cut, as some sustainability issues have been also considered strategic (Baumgartner and Ebner, 2010; Fiksel et al., 2014; Wassmer et al., 2017) such as the use of key natural resources that would put at risk the very survival of a company if these are not managed properly (Hart, 1995; Leisinger, 2015). Therefore, while the management literature has mainly focused on drivers related to business (human, organizational, financial and physical) from an RBV perspective, it is also important to understand how sustainability drivers influence businesses when joining local partnerships. Moreover, there is value in understanding which drivers relate to the SDGs, with the purpose of exploring if the topics of these global goals are connected to business motivations to strategically partner locally for sustainability.

\section{Business outcomes from sustainability partnering}

According to Clarke and Fuller (2010), there are six types of outcomes that can be achieved by organizations when partnering: outcomes about the issues on which the partnerships focus (plan-centric), those that would lead to changes to the partnerships' processes (processcentric), others that affect the relationships between the partnerships and their external stakeholders (outside stakeholder-centric), outcomes that are limited just to particular individuals (person-centric outcomes), outcomes that go beyond the scope of the partnerships (environmental-centric outcomes) and outcomes that alter the behaviour or structure of partner organizations (partner-centric outcomes). This article focuses on partner-centric outcomes.

Outcomes achieved by partners are grouped differently by various authors. They have been clustered according to satisfaction levels or evidence in meeting objectives, enhanced performance in developing tasks and satisfied stakeholders (Brinkerhoff, 2002). They are also grouped according to the creation of capital; the formation of new partnerships, joint actions and the implementation of agreements; and cooperation with other organizations, results and the creation of new institutions, norms and modes of discourse (Bryson et al., 2006). Outcomes have also been named associational outcomes when referring to credibility and respect; transferable outcomes that are about money and skills; interaction outcomes such as trust and reputation; and synergistic outcomes, which include the creation of environmental, economic and social value (Austin and Seitanidi, 2012).

From a management perspective, outcomes are strategic resources that organizations cannot develop on their own, which generate knowledge or political resources that help to influence others (Hardy et al., 2003). RBV has been used to study partner outcomes (Clarke and MacDonald, 2019; Lavie, 2006; Lin, 2012) through physical/financial capital to include identifying funding, cost savings, improving efficiency and accessing new markets (Clarke and MacDonald, 2019; Eisenhardt and Schoonhoven, 1996; Lavie, 2006); social capital to include improving reputation and influence, building relationships; organizational capital to include the increasing impact on organizational sustainability (Clarke and MacDonald, 2019; Hardy et al., 2003; Seitanidi and Crane, 2009); and human capital to include gaining learning and knowledge (Clarke and MacDonald, 2019; Hardy et al., 2003; Selsky and Parker, 2005).
Sustainable development goals

1245 
SAMPJ

12,6

\section{6}

However, despite the wide use of RBV most research has focused on business-related outcomes (human, organizational, physical and financial), with limited attention given to outcomes related to improving the conditions of society, i.e. sustainability-outcomes, which are the main purpose of the local sustainability partnerships and the SDGs. Thus, there is a need to better understand how businesses value the resources they obtain from partnering for local sustainability, and whether those resources have an impact on the achievement of the SDGs.

\section{Methods}

The study used a mixed-methods approach to answer the proposed research questions. Firstly, quantitative analyses were conducted using survey data collected from businesses that have partnered for local sustainability. The results of these analyses shed light on the business drivers that prompt firms to join local sustainability partnerships and the outcomes that these partners experience from participating in these partnerships. Secondly, a qualitative content analysis was conducted to assess the degree to which partners prioritized business drivers and realized outcomes link to the SDGs. The results of the content analysis were used to determine whether local sustainability partnerships can help businesses to contribute to the attainment of the SDGs. The section presents how cases were selected, the sample, survey and measures used and the content analysis process.

\section{Sample and procedure}

This research analysed business partners from four CSSPs.

\section{Case selection}

The CSSP cases were selected on the basis of these criteria (Eisenhardt, 1989), namely, the partnership must implement a strategic community sustainability plan with at least 100 partner organizations, the partnership must include partners from all three sectors (i.e. public, private and civil society sectors), the partners must be actively engaged in implementing the plan's goals (i.e. committing to at least one of the goals of the plan) (Waddock, 1991), the partnership must be at least 10 years old to allow for outcomes to have occurred and the partnership's activities must impact a community with a population of 1-2 million people in a developed country as these cities have more capacity to address sustainability issues (Hawkins et al., 2016). These criteria were used to guide case selection enabling sufficient partners to be assessed from large CSSPs in comparable contexts (i.e. developed economies and mid-sized cities). Table 1 shows the selected CSSPs.

\begin{tabular}{|c|c|c|c|c|c|}
\hline $\begin{array}{l}\text { Partnership[2] (community and } \\
\text { country) }\end{array}$ & $\begin{array}{c}\text { Total } \\
\text { active } \\
\text { partners }\end{array}$ & $\begin{array}{c}\text { Active } \\
\text { business } \\
\text { partners }\end{array}$ & $\begin{array}{l}\text { Business } \\
\text { partner } \\
\text { responses }\end{array}$ & $\begin{array}{l}\text { Partnership } \\
\text { timeframe }\end{array}$ & $\begin{array}{l}\text { Impacted } \\
\text { population[3] } \\
\text { (millions) }\end{array}$ \\
\hline \multirow{4}{*}{$\begin{array}{l}\text { Barcelona + sustainable (Barcelona, } \\
\text { Spain) } \\
\text { Bristol green capital partnership } \\
\text { (Bristol, UK) } \\
\text { Gwangju council for sustainable } \\
\text { development (Gwangju, South Korea) } \\
\text { Sustainable Montreal (Montreal, } \\
\text { Canada) }\end{array}$} & 328 & 156 & 38 & 2002-2022 & 1.6 \\
\hline & 291 & 146 & 12 & 2003-2050 & 1.1 \\
\hline & 111 & 20 & 9 & 1995-2021 & 1.5 \\
\hline & 280 & 45 & 12 & 2005-2020 & 1.7 \\
\hline
\end{tabular}

\section{Canada)}

Table 1.

Participating crosssector sustainability partnerships 
Barcelona + Sustainable started working on sustainability issues during the late 1990s and it is currently implementing its Public Commitment towards Sustainability based on principles of shared responsibility and citizen participation (Secretaría Barcelona+Sostenible, 2021). The initiative's current objectives are focused on 10 key areas, namely, biodiversity, public spaces and mobility, environmental quality and health, efficiency, productivity and zero emissions, rational use of resources, good governance and social responsibility, well-being, progress and development, education and citizen action and resilience and planetary responsibility (Ayuntamiento de Barcelona, 2012).

Bristol Green Capital Partnership has worked towards the sustainability of Bristol since 2007 and has committed to making Bristol a "low-carbon city with a high quality of life" (Bristol Green Capital Partnership, 2018). This CSSP is under the leadership of the Bristol City Council (Bristol Green Capital Partnership, 2018). The partnership is organized around five themes, namely, food, energy, nature, resources and transport. It is currently developing projects on crowdfunding; exclusion of minorities; health, skills and leadership; the SDGs; networking and collaboration; and the development of a resilient, prosperous, healthy and sustainable city (Bristol Green Capital Partnership, 2018).

Gwangju Council for Sustainable Development began its sustainability journey in the 1990s, although under the name Council for Green Gwangju 21 (Gwangju Council for Sustainable Development, 2016). Since then, five action plans have been in the process of implementation. The most current plan was designed under the principles of governance based on public-private cooperation and democratic settlement process in the region, and works towards implementing the SDGs (Gwangju Council for Sustainable Development, 2017). The partnership's current agenda has 17 goals across 10 topic areas, namely, clean water, air and energy, city forests, a city safe from chemicals, recycling of materials, green and social economy, urban farming, welfare, sharing, diverse, healthy and beautiful community, people-oriented traffic system, residential environments and education for sustainability (Gwangju Council for Sustainable Development, 2017).

Sustainable Montreal adopted its first strategic plan for the city in 2005 (Ville de Montréal, 2021) and it is currently working on its third Community Sustainable Development Plan (Ville de Montréal, 2016). This new plan seeks to make Montreal a low carbon, equitable and exemplary city, with four priorities areas, namely, reducing greenhouse gas (GHG) emissions and dependence on fossil fuels, adding vegetation, increasing biodiversity and ensuring the continuity of resources, ensuring access to sustainable, human-scale and healthy neighbourhoods and making the transition towards a green, circular and responsible economy (Ville de Montréal, 2016).

\section{Sample}

Data were collected with an online cross-sectional survey over a two-year timeframe. The survey was designed in English and further translated into the languages of three of the four CSSPs (French, Korean and Spanish and one in English). The surveys were translated using a source-to-target language protocol to reduce translation bias (Smith, 2010).

The study sample represents data collected from 71 business partners, representing $19 \%$ of the total active business partners from the selected CSSPs. One representative per business responded to the survey.

The sample is representative of business across all sizes and is composed of $53 \%$ very small businesses (less than 50 employees), 1\% small-sized businesses (51-99 employees), $21 \%$ medium-sized businesses (100-499 employees) and 24\% large companies (500+ employees). Moreover, the sample captures the duration of the business partner's involvement, where $17 \%$ of businesses report partnering for $10+$ years, $18 \%$ report between 
SAMPJ

12,6

5-10years, $50 \%$ report between $1-5$ years and $15 \%$ report less than 1 year. Nearly all survey participants represent an organization that has voluntarily joined one of the partnerships $(94 \%)$.

Most of the representatives who responded to the survey hold senior or managerial positions in their organization. The sample includes survey data from senior executives, including board members, chief executive officers (CEOs), senior administrators, owners and business partners (49\%); and middle managers (30\%). Responses were also received from junior staff (7\%), external advisors (4\%) and others (10\%).

\section{Survey and measures}

Prior case study research on sustainability CSSPs, as well as literature review on business drivers and outcomes, informed the development of the constructs assessed for this study.

The survey consisted of four sections. The first section collected general information from the partner organizations. The second focused on partner drivers for joining the partnerships. The third on partner structural features for partnerships activity. The fourth collected data on partners' perceptions of their realized outcomes. The central analysis and findings of this study are based on the data collected in the second and fourth sections of the survey. Potential priming effect was reduced by introducing the section about structural features in between the questions on drivers and the ones about outcomes (Schwartz and Schuman, 1997; Sudman et al., 1996). Moreover, introductory texts were presented before the partners responded to the respective sections, with the purpose of helping survey respondents to think about the moment when they joined the partnership when valuing drivers, and the present when valuing the realized outcomes (OECD, 2013).

The survey asked business representatives to rate on a 5-point Likert scale (from 1: most valuable to 5: least valuable) 31 drivers that prompted their organization's decisions to join a local sustainability partnership. Using the same 5-point Likert scale respondents were also asked to rate 31 realized outcomes from partnering for local sustainability. Drivers and outcomes were organized based on the five types of capital proposed by the RBV and sustainability literature, namely, human, organizational, financial, physical and sustainability. The list of 31 drivers and 31 outcomes is presented in Appendix I.

To detect potential response biases a wave analysis was completed by comparing responses from early respondents (15\% who responded first) with late respondents as a proxy for non-respondents (15\% who responded last) on drivers and outcomes (Lewis et al., 2013). Means of survey responses were assessed using independent $t$-tests (Lankford et al., 1995). The results of the $t$-tests indicate that variances between groups for drivers $(p>0.05)$ and outcomes $(\phi>0.01)$ can be assumed to be equal (Levene's test) as no significant differences were identified. Thus, no response bias was detected. Similar results were found among the four partnerships $(\phi \geq 0.05)$, finding no response bias.

Methods such as eliminating the interviewer, offering anonymity (Krosnick and Presser, 2010), self-administration or a private interview setting (Tourangeau and Yan, 2007), were all used to reduce social desirability response bias. Cronbach's $\alpha$ s were calculated to test reliability and indicate internal consistency among constructs $(\alpha>0.70)$ (Cronbach, 1951; Litwin, 1995) (Appendix II).

\section{Content analysis}

A qualitative content analysis of the SDGs' descriptions and targets was conducted (United Nations Development Programme, 2020). The aim of this analysis was to identify whether the SDGs could be linked to the business drivers and outcomes that were assessed in our study. Drivers were conceptualized as reasons that motivated businesses to join 
sustainability partnerships and outcomes as what businesses actually achieved thanks for partnering for local sustainability. Keywords were used to assess all business drivers and outcomes and connect them with the SDGs. While drivers and outcomes are represented by single phrases such as "engaging/engaged with the community" or "sharing/shared own experiences", respectively, the SDGs present a rich content that was examined to understand their purposes and how these were linked to drivers and outcomes. As an example of the content presented, SDG\#1 - no poverty includes an introductory paragraph and six targets referring to the reduction of people living in poverty; the implementation of social protection systems; equal rights to resources and services; building resilience against economic, social and environmental disasters; mobilization of resources; and the creation of sound development strategies for the poor. SDG\#1 and its targets were matched with the driver "engaging with the community" and the outcome "engaged with the community" using keywords such as engagement, collaboration, accord, agreement, community, association and society. This process was conducted for all business drivers and outcomes listed in each of the five categories. Coding was completed separately by two coders.

The content analysis followed a four-step protocol. Firstly, descriptions of the SDGs and their targets were analysed for their potential relationships to business drivers through the use of keywords. Secondly, a structured categorization matrix was created with business drivers organized in rows and the SDGs in columns (Elo and Kyngäs, 2008). Thirdly, when a driver emerged as a potential theme in the SDG content, the respective intersection was marked (Yin, 2014). Fourthly, a data reduction process was used, assigning found themes into one of the five capitals categories (i.e. societal, human, organizational, financial and physical) to determine potential patterns according to the capitals.

The same four-step protocol was followed to relate business outcomes to the SDGs. The descriptions of the SDGs and their targets were analysed looking for possible connections between business outcomes gained from participating in a local sustainability partnership and the SDGs, establishing intersections in a matrix by cross-referencing outcomes with the SDGs. Results were again reduced according to the five capitals.

\section{Results}

The results section is organized according to the research questions into two subsections. Firstly, the survey results are presented informing business drivers and outcomes and the second subsection presents the results obtained from the content analysis.

\section{Survey results: Business partner drivers and outcomes}

As shown in Table 2, the survey results on drivers indicate that businesses that join local sustainability partnerships are motivated to do so primarily by sustainability drivers. The drivers rated as most valuable - contributing positively to environmental challenges $(M=$ 1.45 , Mode $=1, S D=0.73$ ) and contributing positively to the sustainability of the community $(M=1.48$, Mode $=1, S D=0.58)$ - correspond to sustainability capital. Organizational capital drivers were also rated highly, indicating that business partners also join sustainability partnerships to build new relationships $(M=1.58$, Mode $=1, S D=0.71)$ and engage with the community $(M=1.63, M o d e=1, S D=0.87)$. Conversely, indicators of financial capital, a driver that is typically associated with business, were rated as least valuable, improving financial performance $(M=3.20$, Mode $=3, S D=1.18)$ and increasing financial resources $(M=3.23$, Mode $=3, S D=1.23)$. The complete list of drivers is presented in Table 2 , appearing in order from highest $(1=$ most valuable) to the lowest $(5=$ least valuable) rated. 


\section{SAMPJ 12,6}

\section{0}

\begin{tabular}{|c|c|c|c|}
\hline Type of capital & $M$ & Mode & $S D$ \\
\hline Sustainability & 1.45 & 1 & 0.73 \\
\hline Sustainability & 1.48 & 1 & 0.58 \\
\hline Organizational & 1.58 & 1 & 0.71 \\
\hline Organizational & 1.63 & 1 & 0.87 \\
\hline Organizational & 1.73 & 1 & 0.98 \\
\hline Human & 1.75 & 2 & 0.79 \\
\hline Organizational & 1.77 & 1 & 0.87 \\
\hline Organizational & 1.77 & 1 & 1.02 \\
\hline Sustainability & 1.80 & 2 & 0.73 \\
\hline Sustainability & 1.83 & 2 & 0.76 \\
\hline Human & 1.92 & 1 & 0.91 \\
\hline Organizational & 1.96 & 1 & 1.05 \\
\hline Human & 2.06 & 2 & 0.97 \\
\hline Organizational & 2.07 & 1 & 1.00 \\
\hline Organizational & 2.08 & 2 & 1.02 \\
\hline Organizational & 2.11 & 2 & 1.04 \\
\hline Human & 2.14 & 2 & 1.02 \\
\hline Sustainability & 2.15 & 2 & 0.92 \\
\hline Organizational & 2.23 & 2 & 1.04 \\
\hline Organizational & 2.35 & 1 & 1.27 \\
\hline Organizational & 2.38 & 2 & 1.22 \\
\hline Organizational & 2.49 & 3 & 1.16 \\
\hline Financial & 2.70 & 2 & 1.28 \\
\hline Financial & 2.72 & 2 & 1.26 \\
\hline Financial & 3.00 & 3 & 1.26 \\
\hline Physical & 3.01 & 3 & 1.22 \\
\hline Financial & 3.07 & 3 & 1.26 \\
\hline Financial & 3.13 & 3 & 1.23 \\
\hline Physical & 3.15 & 3 & 1.25 \\
\hline Financial & 3.20 & 3 & 1.18 \\
\hline Financial & 3.23 & 3 & 1.23 \\
\hline
\end{tabular}

When the drivers were collapsed to compose the five capital categories slightly different results emerged. While sustainability capital still received the best overall mean score $(M=$ 1.74), human capital had a slightly better mean score $(M=1.96)$ than organizational capital $(M=2.01)$. Likewise, physical capital $(M=3.08)$ rather than financial capital $(M=3.01)$ was ranked as the least valuable overall. These results indicate that business partners are initially motivated to join sustainability partnerships because of the prospect of gaining sustainability, human and organizational capital. They also show that for business partners, physical and financial capitals are less important considerations when compared to the other capitals assessed. The results for all five capitals as drivers to partners are shown in Table 3.

Table 4 provides the list of outcomes arranged from highest $(1=$ most valuable) to the lowest ( $5=$ least valuable) rated. The survey results on partnering outcomes reveal that the two outcomes most valued by businesses correspond to the organizational and human capital categories, where built new relationships $(M=1.99, S D=0.88)$ and shared own experiences $(M=2.00, S D=1.02)$ have the best mean scores, respectively. The outcomes contributed positively to environmental challenges $(M=2.01, S D=1.08)$ and networking $(M=2.06, S D=1.03)$, received similarly high mean scores. When evaluating the mode values, shared own experiences $($ Mode $=1)$, contributed positively to environmental 
challenges $($ Mode $=1)$ and networking $(M o d e=1)$, were most frequently rated as most valuable. While the mode for built new relationships (Mode $=2$ ), was most often rated as only valuable. Thus, by this measure, the top two outcomes are related to the sustainability and human capital categories. The outcome rated as least valuable overall was increased financial resources, remaining at the bottom of this list for outcomes $(M=3.67$, Mode $=3$, $S D=1.15)$ and for drivers.
Sustainable development goals

1251

\begin{tabular}{lccc}
\hline Type of capital & $M$ & Mode & $S D$ \\
\hline Sustainability & 1.74 & 1 & 0.79 \\
Human & 1.96 & 2 & 0.93 \\
Organizational & 2.01 & 1 & 1.06 \\
Financial & 3.01 & 3 & 1.24 \\
Physical & 3.08 & 3 & 1.23
\end{tabular}

Note: Means from 1: most valuable, to 5: least valuable
1.23
Table 3.

List of drivers to partner according to the five capitals

\begin{tabular}{|c|c|c|c|c|c|}
\hline Outcome & Type of capital & $M$ & Mode & $S D$ & \\
\hline Built new relationships & Organizational & 1.99 & 2 & 0.88 & \\
\hline Shared own experiences & Human & 2.00 & 1 & 1.02 & \\
\hline Contributed positively to environmental challenges & Sustainability & 2.01 & 1 & 1.08 & \\
\hline Networking & Organizational & 2.06 & 1 & 1.03 & \\
\hline Gained knowledge/learning & Human & 2.09 & 2 & 0.97 & \\
\hline Contributed positively to community sustainability & Sustainability & 2.10 & 1 & 1.13 & \\
\hline Engaged with the community & Organizational & 2.12 & 1 & 1.14 & \\
\hline Improved reputation & Organizational & 2.15 & 2 & 0.96 & \\
\hline Collaborated with others & Organizational & 2.24 & 2 & 1.07 & \\
\hline Contributed positively to social challenges & Sustainability & 2.27 & 2 & 1.07 & \\
\hline Gained expertise & Human & 2.27 & 2 & 1.08 & \\
\hline Contributed to the plan's sustainability goals & Sustainability & 2.33 & 2 & 1.04 & \\
\hline Improved the organization's sustainability & Organizational & 2.37 & 2 & 1.15 & \\
\hline Gained legitimacy & Organizational & 2.43 & 2 & 1.06 & \\
\hline Improved competencies & Human & 2.45 & 2 & 1.10 & \\
\hline Became more influential & Organizational & 2.57 & 3 & 0.99 & \\
\hline Developed innovation capacity & Organizational & 2.60 & 2 & 1.09 & \\
\hline Found marketing opportunities & Organizational & 2.69 & 3 & 1.03 & \\
\hline Improved relationship with authorities & Organizational & 2.69 & 3 & 1.12 & \\
\hline Accessed new markets & Organizational & 2.70 & 3 & 1.10 & \\
\hline Contributed positively to economic challenges & Sustainability & 2.72 & 3 & 1.15 & \\
\hline Improved relationship with NGOs & Organizational & 2.85 & 3 & 1.21 & \\
\hline Improved processes & Physical & 3.30 & 3 & 1.29 & \\
\hline Made new businesses & Financial & 3.33 & 3 & 1.22 & \\
\hline Developed new products/services & Financial & 3.34 & 3 & 1.27 & \\
\hline Reduced costs & Financial & 3.42 & 3 & 1.29 & labi \\
\hline Improved financial performance & Financial & 3.45 & 3 & 1.13 & List of achieved \\
\hline Increased resources & Physical & 3.46 & 3 & 1.27 & outcomes from the \\
\hline Found funding opportunities & Financial & 3.48 & 3 & 1.15 & most to least \\
\hline Attracted new investors & Financial & 3.63 & 3 & 1.19 & valuable as rated by \\
\hline Increased financial resources & Financial & 3.67 & 3 & 1.15 & business partners \\
\hline
\end{tabular}


SAMPJ

12,6

1252

As shown in Table 5, the results for outcomes by capital category show that overall outcomes linked to human capital were rated as most valuable $(M=2.20$, Mode $=2, S D=$ 1.05). While indicators linked to sustainability capital were the primary drivers for businesses to join a partnership, ultimately the outcomes that businesses most values are linked to human capital. The lowest-ranked outcomes are linked to the financial capital category $(M=3.47$, Mode $=3, S D=1.20)$, whereas indicators linked to physical capital were expected to be least valuable when businesses rated their drivers for partnering.

Content analysis results: Business interests and the sustainable development goals

The results of the content analysis show that the highest-rated business drivers could be achieved by targeting the SDGs and that the realized outcomes contribute to the achievement of the SDGs. In other words, businesses can use the SDGs as a framework to guide them towards realizing their aims for joining local sustainability partnerships, while contributing to the achievement of the SDGs through the realized outcomes from partnering.

The content analysis of the SDGs in light of our survey findings on business drivers finds that contributing positively to environmental challenges, the highest-rated driver, is linked to most of the SDGs. As an example presented in Figure 1, 13 of the SDGs have environmental targets that are associated with their achievement. Likewise, the second highest-rated driver, which is also from the sustainability category (contributing positively to community sustainability) and the third (building new relationships), are linked to all the SDGs. The SDGs were also examined in relation to the drivers in their composite form. These results indicate that sustainability, organizational and human capital share the most overlap with the SDGs, respectively. A graphical representation of the relationships between the SDGs and business drivers per type of capital is shown in Figure 2.

Most importantly, with respect to the reported outcomes achieved by businesses when partnering for local sustainability, results show that they have the potential to contribute to the achievement of the SDGs. For example, one of the highest-rated outcomes, engaged with the community could - depending on the specific project or initiative for which community engagement occurred - contribute to the aims of several SDGs. For example, to sustainability goals such as SDG\#1 (no poverty) through targeting the most vulnerable; SDG\#5 (gender equality) by ending all forms of discrimination; and SDG\#12 (sustainable production and consumption) by encouraging industries, business and consumers to recycle and reduce their waste; among other SDGs. Similarly, another of the highest-rated outcomes, contributing positively to the sustainability of the community could contribute to the achievement of SDG\#6 (clean water and sanitation) providing access to drinkable water and sanitation for all; SDG\#8 (decent work and economic growth) by contributing to full employment, decent work and equal pay for all; SDG\#10 (reduced inequalities) ensuring equal opportunities and reducing inequalities; and SDG\#11 (sustainable cities and

Table 5.

List of achieved outcomes according to the five capitals

\begin{tabular}{lccc}
\hline Type of capital & $M$ & Mode & $S D$ \\
\hline Human & 2.20 & 2 & 1.05 \\
Sustainability & 2.29 & 2 & 1.11 \\
Organizational & 2.42 & 2 & 1.09 \\
Physical & 3.38 & 3 & 1.28 \\
Financial & 3.47 & 3 & 1.20
\end{tabular}

Note: Means from 1: most valuable, to 5: least valuable 

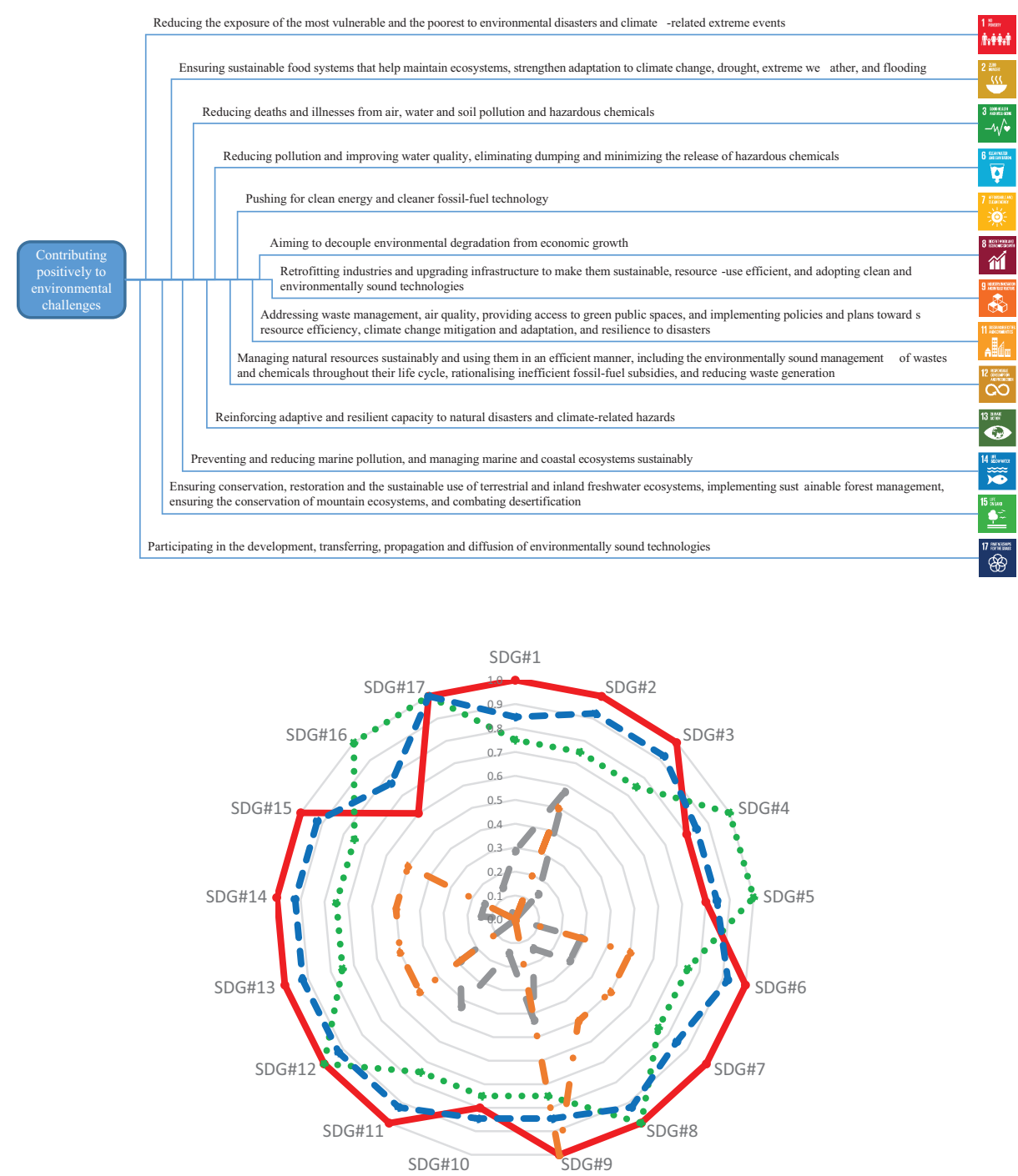

$\leadsto$ Sustainability • Human $\leftrightarrow$ Organizational

Financia

Physical

communities) contributing to the attainment of adequate, safe and affordable basic services and housing for all. Figure 3 shows the identified connections between the outcome engaged with the community and SDG targets. Then, when collapsed into their composite capital categories, outcomes associated with sustainability and human capital were found to have the most overlap with the SDGs. Shown in Figure 4 is a graphical representation of the relationships between the 17 SDGs and business outcomes per capital.

Going one step further, the 10 highest-rated drivers and outcomes were analysed versus their relationship with the SDGs finding a 90\% match between the 10 most valuable drivers
Sustainable development goals

1253

Figure 1.

Links between businesses highest rated driver and the SDGs

Figure 2.

Relationships between the SDGs and business drivers per capital 


\section{Figure 3.}

Links between one of businesses highestrated outcomes and the SDGs
Figure 4.

Relationships between business outcomes per capital and the SDGs
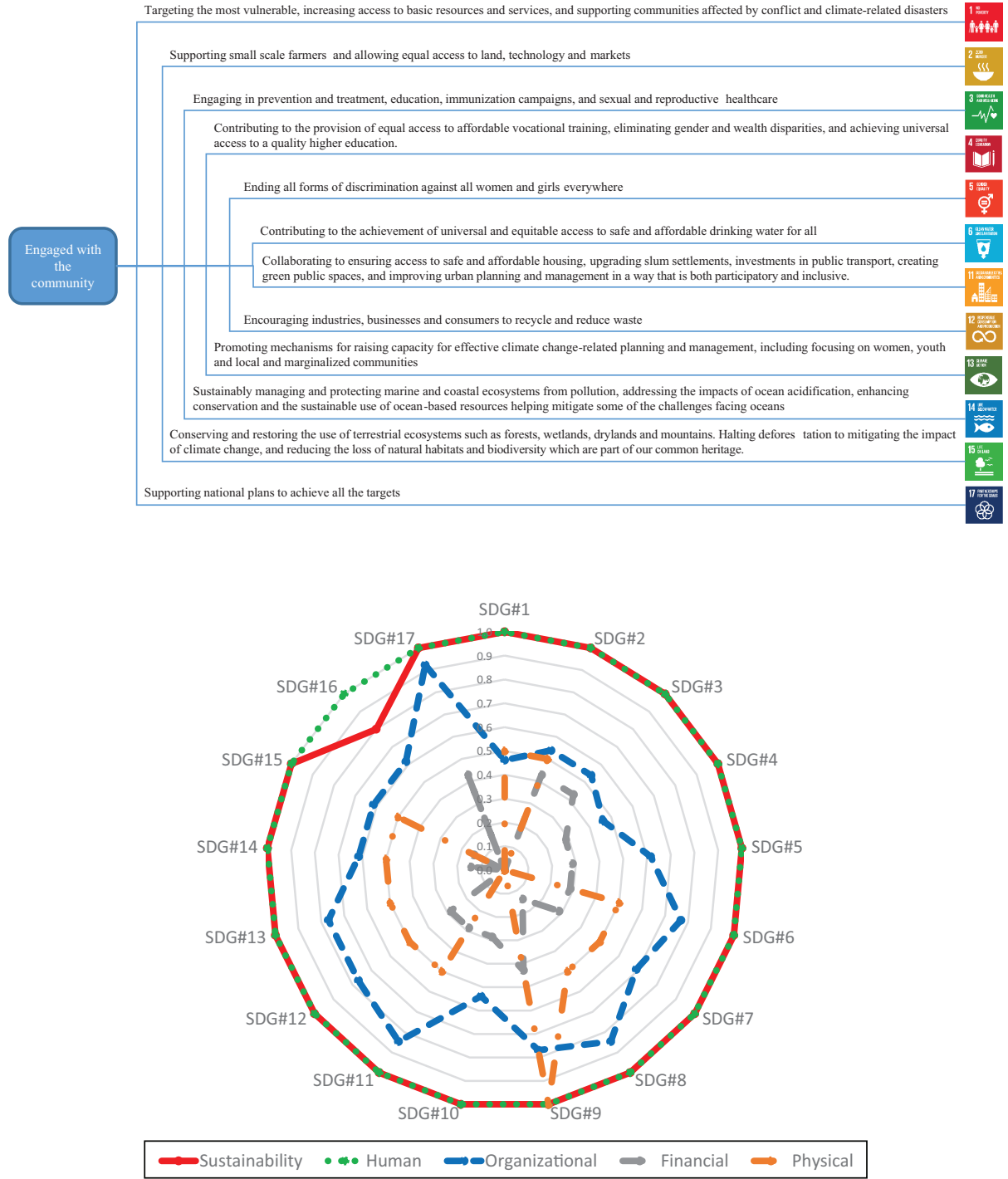

and outcomes and that sustainability, human and organizational capital have a high connection to the global goals. Interestingly, while organizational capital are the drivers most linked to the SDGs, these are the outcomes least linked to the SDGs, among the three top categories. Similarly, human capital were found to be the outcomes most contributing to the SDGs, whereas these are the drivers least linked to the SDGs. Figure 5 shows the connections between the 10 highest-rated drivers and outcomes per category versus the SDGs.

In sum, the survey and content analysis results indicate that sustainability, human and organizational drivers, as well as outcomes are the highest-rated for businesses that partner 

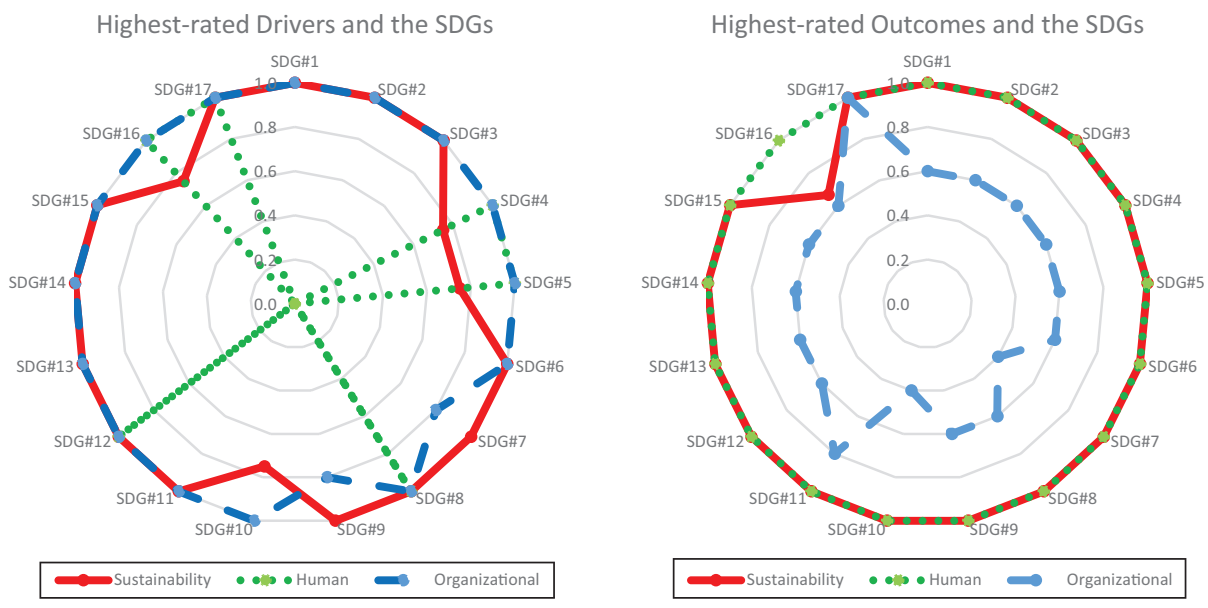

Sustainable
development
goals

for local sustainability and that these have significant overlap with the SDGs. These results suggest that local sustainability partnerships can create a path towards achieving the SDGs and their targets. Furthermore, it can also be argued that the global goals could represent a motivation for engaging in local sustainability partnerships.

These findings inform the development of a conceptual model that combines businesses' drivers and outcomes with the SDGs in a positive relationship. As illustrated in Figure 6, the SDGs, which can be understood as a proxy for global sustainability, can represent a motivation and an opportunity for businesses to consider for joining local sustainability partnerships, while their outcomes from partnering at the local level can contribute to the achievement of the SDGs and global sustainability. This positive cycle could be implemented by those leading local sustainability partnerships and those promoting the SDGs by connecting the global goals as a sustainability framework, with local partnerships contributing from the local to the global level. This is especially relevant considering a large number of existing local sustainability partnerships (Moallemi et al., 2019; Rok and Kuhn, 2012) and the remaining global sustainability challenges (Sachs et al., 2020).

\section{Discussion}

Many scholars assert that businesses are key to the success of the SDGs (Rosati and Faria, 2019; Sachs, 2012; Scheyvens et al., 2016) and, increasingly businesses are partnering with

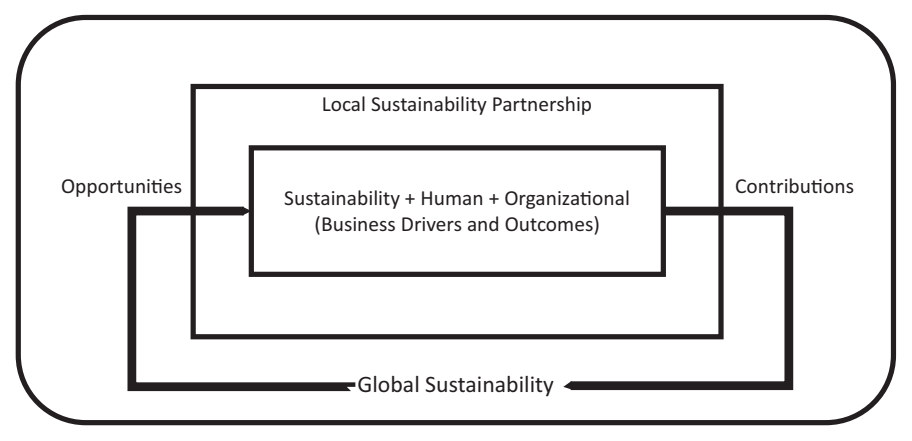

Figure 6.

Business drivers and outcomes in relation to global sustainability 
SAMPJ

12,6

other organizations to address sustainability issues in the communities where they operate (George et al., 2016). In doing so, businesses are assuming their fundamental responsibilities and roles within society (Hsieh, 2017). Similarly, scholars and the international community have suggested that partnerships are crucial for sustainable development (Koontz, 2006; United Nations Development Programme, 2020), and worldwide local governments pursue their community's sustainability vision in partnership with local stakeholders (Moallemi et al., 2019). Furthermore, LA21 and local sustainability goals have been found to be wellaligned with the SDGs (MacDonald et al., 2018; Salvia et al., 2019). While all of this suggests that local sustainability partnerships create opportunities for businesses to contribute to achieving the SDGs, usual business practices must change for them to make tangible contributions to global sustainability (Scheyvens et al., 2016), collectively aligning to ensure local actions lead to global progress, thus addressing issues of scale (Bansal et al., 2018). The research presented in this article sought to understand whether local sustainability partnerships can help businesses to contribute to the attainment of the SDGs, and in doing so also highlighted the resources to be gained by businesses from partnering for sustainability.

Business drivers and outcomes: Support for the social motives resource perspective Scholars who adopt a resource perspective to understand why businesses join partnerships are not in agreement about what motivates businesses to engage in this behaviour. On one hand, scholars propose that businesses are motivated by strategic ends to join partnerships (Eisenhardt and Schoonhoven, 1996), while others argue that they partner for social or altruistic reasons (Vurro et al., 2010), with a clear trend of business and management scholars focusing on the former. However, as this study focuses on sustainability, a sustainability dimension was added to the rationale finding sustainability business drivers and outcomes among the highest-rated, supporting the "social motives" perspective over the purely strategic approach. This research actually shows that it is likely both social and strategic motivations. It is possible to view these findings as tautological and explained by the characteristics of the partnerships and partners (large partnerships, long-term commitment, $35 \%$ partnering for $5+$ years, engaged voluntarily and largely satisfied with the outcomes), meaning that they have shown a commitment to sustainability, and are thus, likely to consider it valuable. These results show a positive sign when trying to connect businesses, local partnerships and the SDGs. Nevertheless, these also point to positive developments in terms of the ways in which the business sector is viewing local sustainability, especially when considering the drivers that prompted the businesses in this study to join a local sustainability partnership. Also, with so few small- and medium-sized enterprises engaged with the SDGs (Verboven and Vanherck, 2016), local partnerships can enable both local and global progress, regardless of if their motivations are global or local, thus addressing both scales.

\section{Business interests and the sustainable development goals: understanding where the two connect}

Our findings reveal linkages between what drives businesses to partner for local sustainability and the global SDGs, as well as business outcomes from partnering and the SDGs. When local sustainability partnerships help business partners to gain sustainability, human and organizational resources, they are also providing businesses and the partnership with a way to make positive contributions to global sustainability. These findings could be seen as a positive indication, highlighting the SDGs not only as a business opportunity but 
also for businesses to move beyond business-as-usual and assume commitments to address societal challenges.

The results of our analysis that focused on the top drivers and outcomes and their overlap with the SDGs, found that the decision made by businesses to join a partnership was driven by the expectation that their involvement would contribute to sustainability capital. Indeed the drivers "contributing positively to environmental challenges" and "contributing positively to community sustainability" were expected by business partners to be most valued. These results suggest a significant overlap between business drivers to partner for development goals sustainability and the SDGs, especially given our additional finding that the sustainability capital indicators are strongly aligned with the SDGs. However, as outcomes, the sustainability capital indicators received lower value ratings from business partners. In contrast, indicators for organizational and human capitals, which are less aligned with the SDGs, were ranked among the most valued outcomes by business partners.

There are two potential explanations for these findings. The first is that business partners overestimated the contributions that they would make to local sustainability through the partnership, and as a result of less than expected sustainability outcomes they lowered their ranking of the value of sustainability capital. The second is that business partners underestimated the value that organizational and human capital outcomes would create for their organization, and so they promoted the value of these as realized outcomes. If it is the former, then one implication could be that local sustainability partnerships need to be more proactive in creating opportunities for business partners to positively contribute to local sustainability. Alternately, it could also be that business partners need to be more ambitious with their commitments and contributions to the partnership and local sustainability (Lam et al., 2020).

\section{Local Agenda 21s and the sustainable development goals}

The potential for LA21s to place greater emphasis towards their extant SDG components was a particularly interesting finding of our research. LA21s propose collaborative strategic management processes for implementing local sustainable development strategies (Clarke and Fuller, 2010), recognizing the power of local cross-sector partnerships to achieve sustainable development (United Nations, 1992). However, although they have been implemented all over the world since 1992 (Moallemi et al., 2019; Rok and Kuhn, 2012), updated understandings of sustainable development have emerged through initiatives such as the New Urban Agenda (United Nations Habitat, 2016), the Paris Agreement (United Nations, 2015b) and the SDGs, providing new content for LA21s. For example, now that local communities are targeting deep decarbonization in line with the Paris Agreement (e.g. at least $80 \%$ reduction in greenhouse gas emissions by 2050) incremental improvements are no longer an option. Transformational change, by local businesses and other local actors, will be needed to ensure local climate action matches global commitments. Updated LA21s (or other local sustainability plans) recognize these newer goals.

A greater focus on linking LA21 goals and outcomes to the global SDGs could revive this grassroots collaborative approach to addressing local, and thus, global social, ecological and economic issues in a holistic and integrated manner. Sustainable development enables social justice to be considered alongside climate action, for example. Also, LA21s with large crosssector partnerships enable considerable collective action towards SDG implementation. While integrating environmental, social and economic goals through the engagement of local stakeholders (Owen and Videras, 2008), the LA21 process includes the creation of collective sustainability visions (Freeman et al., 1996; Roseland and Spiliotopoulou, 2016) documented in community sustainability plans (Clarke and Fuller, 2010) that are 
SAMPJ

12,6

implemented and monitored by local stakeholders (ICLEI, 2002). While they are not perfect instruments to achieve sustainability have had limited impact on business in some places (Dentchev et al., 2018), poor performance on social issues on others (Lizama-Pérez et al., 2018) and some low participation of stakeholders (Kamaruddin et al., 2016), its cross-sector approach could certainly help to overcome these challenges if appropriately designed (Sun et al., 2020).

Replicating this local approach globally through the thousands of local partnerships addressing sustainability challenges can contribute to global sustainability and the achievement of the SDGs, bringing the strengths of local initiatives to the global scale. However, this is not just an issue of replication but also about how this relates with power that all actors transform into concrete actions to achieve global sustainability (Delaney and Leitner, 1997). While local issues are easier to manage than the global sustainability agenda through collaborative cross-sector approaches (Bowen et al., 2018), local authorities and businesses can expand their local sustainability initiatives and the role that businesses play in addressing local challenges so that the SDGs can be accomplished. The four cross-sector partnerships studied here all have more than 100 active organizational partners involved, enabling considerable collective action.

While this research is exploratory and further research is certainly required, it can be argued that the potential exists, contributing to understanding the local and global impact of partnerships, an area that remains understudied (van Tulder et al., 2016). Based on the number of existing partnerships (Moallemi et al., 2019), how large CSSPs are increasing in numbers (MacDonald et al., 2018) and that businesses are progressively joining others to contribute to sustainability (George et al., 2016), some positive signs can be considered. Nevertheless, the engagement of businesses in local sustainability partnerships requires their true commitment and not to transform their participation into what has been already called "SDG-washing", a trend that the literature has started to report (van Tulder and Lucht, 2019). This is certainly a challenge, but the suggestion that local sustainability partnerships could help businesses to gain resources while contributing to global sustainability is a hopeful sign of potential progress, something certainly needed under the current challenging conditions we face. However, the issue of scale can only be addressed if there is widespread adoption, therefore these efforts can collectively impact global sustainability.

This research suggests that while the SDGs can be presented as a motivation and opportunity for businesses to gain sustainability, organizational and human resources and the outcomes they achieve when partnering for local sustainability can contribute to global sustainability. Therefore, this research recommends for businesses and those leading local sustainability partnerships to consider the SDGs as a sustainability framework that could potentially help businesses reach their highest-rated motivations (namely, sustainability-, human- and organizational-related goals) through contributing to the success of the local partnerships. Then, a virtuous cycle could materialize towards the attainment of outcomes that will contribute to global sustainability, as proposed by Figure 6.

\section{Limitations and future directions}

This research is exploratory in nature, therefore the findings should be interpreted as an indication of the potential that large cross-sector sustainability partnerships could represent to businesses from diverse sizes and industries to achieve their strategic goals and contribute to local and global sustainability while gaining sustainability, organizational and human resources. However, how these partnerships address the issues they are designed to do and whether they certainly do it are still issues pending to be deeply assessed (Clarke and 
Crane, 2018). Further research is encouraged to assess the found relationships and contribute with a deeper understanding of the role that partnerships and partners can play in local and global sustainability. The role that business structures play in between drivers and outcomes is suggested for further research, understanding that structures are key in reaching strategic goals (Andrews, 1980; Ordonez-Ponce and Clarke, 2020). Finally, assessing directly from local businesses what their relationships with the SDGs are and if these are seen as opportunities to achieve their strategic goals are potential research directions.

\section{Conclusion}

Questions of scale are a challenge for management scholars (Bansal et al., 2018), yet are critical to addressing grand challenges (as outlined in the SDGs) (George et al., 2016). This research contributes to practice and the literature by assessing businesses partnering for local sustainability, their relationships to the SDGs and the potential that local sustainability partnerships have to contribute to global sustainability. The value for the business in partnering in local sustainability partnerships is better understood. Noteworthy is the contribution made to the literature on sustainability-related resources showing an expanded perspective of the RBV literature. Secondly, a positive connection has been made between businesses and the global goals, proposing a constructive model of relationship that encapsulates these research findings. And finally, large cross-sector partnerships are better understood.

\section{Notes}

1. Local, community and city are terms used interchangeably throughout the article.

2. Names translated into English.

3. Population does not necessarily refer to the population of the city, but that of the partnerships' geographic impact area.

\section{References}

Alonso, J.M. and Andrews, R. (2019), "Governance by targets and the performance of cross-sector partnerships: do partner diversity and partnership capabilities matter?”, Strategic Management Journal, Vol. 40 No. 4, pp. 556-579.

Andrews, K.R. (1980), The Concept of Corporate Strategy, Richard D. Irwin, Inc., Homewood, IL.

Ansell, C. and Gash, A. (2008), "Collaborative governance in theory and practice", Journal of Public Administration Research and Theory, Vol. 18 No. 4, pp. 543-571.

Austin, J.E. and Seitanidi, M.M. (2012), "Collaborative value creation: a review of partnering between nonprofits and businesses: Part 1. Value creation spectrum and collaboration stages", Nonprofit and Voluntary Sector Quarterly, Vol. 41 No. 5, pp. 726-758.

Ayuntamiento de Barcelona (2012), “Compromiso ciudadano por la sostenibilidad 2012-2022”, available at: http:/ajuntament.barcelona.cat/ecologiaurbana/sites/default/files/Compromiso\%20Ciudadano\%20por $\% 201 a \% 20$ Sostenibilidad.pdf

Babiak, K. and Thibault, L. (2009), "Challenges in multiple cross-sector partnerships”, Nonprofit and Voluntary Sector Quarterly, Vol. 38 No. 1, pp. 117-143.

Bakan, J. (2004), The Corporation. The Pathological Pursuit of Profit and Power, Penguin Group.

Bansal, P., Kim, A. and Wood, M.O. (2018), "Hidden in plain sight: the importance of scale in organizations' attention to issues”, Academy of Management Review, Vol. 43 No. 2, pp. 217-241.
Sustainable development goals

1259 
SAMPJ

12,6

Barney, J.B. (1991), "Firm resources and sustained competitive advantage", Journal of Management, Vol. 17 No. 1, pp. 99-120.

Barney, J.B. (1995), "Looking inside for competitive advantage”, Academy of Management Perspectives, Vol. 9 No. 4, pp. 49-61.

Barney, J.B., Ketchen, D.J., Jr and Wright, M. (2011), “The future of resource-based theory: revitalization or decline?”, Journal of Management, Vol. 37 No. 5, pp. 1299-1315.

Barrutia, J.M., Aguado, I. and Echebarria, C. (2007), "Networking for local agenda 21 implementation: learning from experiences with Udaltalde and Udalsarea in the”, Geoforum”, Vol. 38 No. 1, pp. 33-48.

Baumgartner, R.J. and Ebner, D. (2010), "Corporate sustainability strategies: sustainability profiles and maturity levels", Sustainable Development, Vol. 18 No. 2, pp. 76-89.

Bowen, F., Bansal, P. and Slawinski, N. (2018), "Scale matters: the scale of environmental issues in corporate collective actions", Strategic Management Journal, Vol. 39 No. 5, pp. 1411-1436.

Branzei, O. and Le Ber, M. (2014), "Theory-method interfaces in cross-sector partnership research", in Seitanidi, M.M. and Crane, A. (Eds), Social Partnerships and Responsible Business, Routledge: Taylor and Francis Group, London, pp. 229-266.

Brinkerhoff, J.M. (2002), “Assessing and improving partnership relationships and outcomes: a proposed framework", Evaluation and Program Planning, Vol. 25 No. 3, pp. 215-231.

Bristol Green Capital Partnership (2018), "Bristol green Capital partnership", available at: http:// bristolgreencapital.org/

Bryson, J.M., Crosby, B.C. and Stone, M.M. (2006), “The design and implementation of crosssector collaborations: propositions from the literature", Public Administration Review, Vol. 66 No. s1, pp. 44-55.

City of Kitchener (2019), "Kitchener's strategic plan 2019-2022”, City of Kitchener, available at: www.kitchener. ca/en/resourcesGeneral/Documents/COR_CAO_Kitcheners-Strategic-Plan-accessible_8.5x11.pdf

Clarke, A. and Ordonez-Ponce, E. (2017), "City scale: cross-sector partnerships for implementing local climate mitigation plans", Public Administration Review, available at: https:/publicadministrationreview.org/ speak-your-mind-climate-change-symposium/

Clarke, A. and Crane, A. (2018), "Cross-sector partnerships for systemic change: systematized literature review and agenda for further research", Journal of Business Ethics, Vol. 150 No. 2, pp. 303-313.

Clarke, A. and Fuller, M. (2010), "Collaborative strategic management: strategy formulation and implementation by multi-organizational cross-sector social partnerships", Journal of Business Ethics, Vol. 94, pp. 85-101.

Clarke, A. and MacDonald, A. (2019), "Outcomes to partners in multi-stakeholder cross-sector partnerships: a resource-based view”, Business and Society, Vol. 58 No. 2, pp. 298-332.

Clarke, A., MacDonald, A. and Ordonez-Ponce, E. (2019), "Implementing community sustainability strategies through cross-sector partnerships: Value creation for and by businesses”, in Borland, H., Lindgreen, A., Vanhamme, J., Maon, F., Ambrosini, V. and Palacios Florencio, B. (Eds), Business Strategies for Sustainability: A Research Anthology, Routledge.

Crane, A. and Seitanidi, M.M. (2014), "Social partnerships and responsible business. What, why and how?", in Seitanidi, M.M. and Crane, A. (Eds), Social Partnerships and Responsible Business. A Research Handbook, Routledge: Taylor and Francis, London, pp. 1-12.

Cronbach, L.J. (1951), "Coefficient alpha and the internal structure of tests", Psychometrika, Vol. 16 No. 3, pp. 297-334.

Davis, G.F. and Marquis, C. (2005), "Prospects for organization theory in the early twenty-first century: institutional fields and mechanisms", Organization Science, Vol. 16 No. 4, pp. 332-343.

Delaney, D. and Leitner, H. (1997), "The political construction of scale”, Political Geography, Vol. 16 No. 2, pp. 93-97. 
Dentchev, N.A., Eiselein, P. and Kayaert, T. (2018), "Social responsibility within Brussels municipalities: an exploratory study", Corporate Social Responsibility, Vol. 2, Emerald Group Publishing Limited, pp. 147-174.

Eboli, F., Parrado, R. and Roson, R. (2010), "Climate-change feedback on economic growth: explorations with a dynamic general equilibrium model", Enwiromment and Development Economics, Vol. 15 No. 5, pp. 515-533.

Eisenhardt, K. (1989), "Building theory from case study research", Academy of Management Review, Vol. 14 No. 4, pp. 532-550.

Eisenhardt, K. and Schoonhoven, C.B. (1996), "Resource-based view of strategic alliance formation: strategic and social effects in entrepreneurial firms", Organization Science, Vol. 7 No. 2, pp. 136-150.

ElAlfy, A., Darwish, K.M. and Weber, O. (2020), "Corporations and sustainable development goals communication on social media: corporate social responsibility or just another buzzword?", Sustainable Development, pp. 1-13.

Eliasson, J. (2015), "Battle for sustainable development will be won or lost in cities, deputy secretarygeneral tells mayor's forum”, UN Meetings Coverage and Press Releases, New York, NY, 9 June, available at: www.un.org/press/en/2015/dsgsm874.doc.htm

Elo, S. and Kyngäs, H. (2008), "The qualitative content analysis process", Journal of Advanced Nursing, Vol. 62 No. 1, pp. 107-115.

Fiksel, J., Bruins, R., Gatchett, A., Gilliland, A. and ten Brink, M. (2014), "The triple value model: a systems approach to sustainable solutions", Clean Technologies and Environmental Policy, Vol. 16, pp. 691-702.

Flammer, C. and Bansal, P. (2017), "Does a long-term orientation create value? Evidence from a regression discontinuity”, Strategic Management Journal, Vol. 38 No. 9, pp. 1827-1847.

Fombrun, C.J. and Astley, W.G. (1983), "Beyond corporate strategy”, Journal of Business Strategy, Vol. 3 No. 4, pp. 47-54.

Freeman, C., Littlewood, S. and Whitney, D. (1996), "Local government and emerging models of participation in the local agenda 21 process", Journal of Environmental Planning and Management, Vol. 39 No. 1, pp. 65-78.

George, G., Howard-Grenville, J., Joshi, A. and Tihanyi, L. (2016), “Understanding and tackling societal grand challenges through management research”, Academy of Management Journal, Vol. 59 No. 6, pp. 1880-1895.

Glasbergen, P. (2007), "Setting the scene: the partnership paradigm in the making", in Glasbergen, P., Biermann, F. and Mol, A.P.J. (Eds), Partnerships, Governance and Sustainable Development: Reflections on Theory and Practice, Edward Elgar, Cheltenham, pp. 1-25.

Googins, B.K. and Rochlin, S.A. (2000), "Creating the partnership society: understanding the rhetoric and reality of cross-sectoral partnerships", Business and Society Review, Vol. 105 No. 1, pp. 127-144.

Goworek, H., Land, C., Burt, G., Zundel, M., Saren, M., Parker, M. and Lambe, B. (2018), "Scaling sustainability: regulation and resilience in managerial responses to climate change", British Journal of Management, Vol. 29 No. 2, pp. 209-219.

Gray, B. and Stites, J.P. (2013), Sustainability through Partnerships, Network for Business Sustainability, London, ON.

Griggs, D., Stafford-Smith, M., Gaffney, O., Rockström, J., Öhman, M.C., Shyamsundar, P., Steffen, W., Glaser, G., Kanie, N. and Noble, I. (2013), "Sustainable development goals for people and planet", Nature, Vol. 495 No. 7441, pp. 305-307.

Gusmão Caiado, R.G., Leal Filho, W., Goncalves Quelhas, O.L. and de Mattos Nascimento, D.L. (2018), "A literature-based review on potentials and constraints in the implementation of the sustainable development goals”, Journal of Cleaner Production, Vol. 198, pp. 1276-1288. 
SAMPJ 12,6
Gwangju Council for Sustainable Development (2016), Local Agenda 21, Gwangju Council for Sustainable Development, Gwangju.

Gwangju Council for Sustainable Development (2017), "Gwangju council introduction brochure”.

Hardy, C., Phillips, N. and Lawrence, T.B. (2003), "Resources, knowledge and influence: the organizational effects of interorganizational collaboration", Journal of Management Studies, Vol. 40 No. 2.

Hart, S.L. (1995), “A natural-resource-based view of the firm”, Academy of Management Review, Vol. 20 No. 4, pp. 986-1014.

Hawkins, C.V., Krause, R.M., Feiock, R.C. and Curley, C. (2016), "Making meaningful commitments: accounting for variation in cities' investments of staff and fiscal resources to sustainability", Urban Studies, Vol. 53 No. 9, pp. 1902-1924.

Hsieh, N. (2017), "The responsibilities and role of business in relation to society: back to basics?", Business Ethics Quarterly, Vol. 27 No. 2, pp. 293-314.

ICLEI (1997), "Local agenda 21 survey, united nations commission on sustainable development", available at: www.un.org/documents/ecosoc/cn17/1997/background/ecn171997-1.rpt1.htm

ICLEI (2002), “Second Local Agenda 21 Survey - Background Paper No. 15”, ICLEI.

Jones, P., Hillier, D. and Comfort, D. (2016), "The sustainable development goals and business", International Journal of Sales, Retailing and Marketing, Vol. 5 No. 2, pp. 38-48.

Kalesnikaite, V. (2019), "Keeping cities afloat: climate change adaptation and collaborative governance at the local level", Public Performance and Management Review, Vol. 42 No. 4, pp. 864-888.

Kamaruddin, S., Ahmad, P. and Alwee, N. (2016), "Community awareness on environmental management through local agenda 21 (LA21)", Procedia - Social and Behavioral Sciences, Vol. 222, pp. 726-737.

Kolk, A., Kourula, A. and Pisani, N. (2017), "Multinational enterprises and the sustainable development goals: what do We know and how to proceed?", Transnational Corporations, Vol. 24 No. 3, pp. 9-32.

Kolk, A., van Dolen, W. and Vock, M. (2010), "Trickle effects of cross-sector social partnerships", Journal of Business Ethics, Vol. 94, pp. 123-137.

Koontz, T.M. (2006), "Collaboration for sustainability? A framework for analyzing government impacts in collaborative-environmental management”, Sustainability: Science, Practice, and Policy, Vol. 2 No. 1, pp. 15-24.

Krosnick, J.A. and Presser, S. (2010), "Question and questionnaire design”, in Marsden, P.V. and Wright, J.D. (Eds), Handbook of Survey Research, 2nd ed., Emerald Group Publishing Limited, Bingley, UK, pp. 263-313.

Kythreotis, A.P. and Jones, A.E.G. (2012), "Scaling sustainable development? How voluntary groups negotiate spaces of sustainability governance in the United Kingdom", Environment and Planning D: Society and Space, Vol. 30 No. 3, doi: 10.1068/d11810.

Laasonen, S., Fougère, M. and Kourula, A. (2012), "Dominant articulations in academic business and society discourse on NGO-business relations: a critical assessment", Journal of Business Ethics, Vol. 109 No. 4, pp. 521-545.

Lam, D.P.M., Martín-López, B., Wiek, A., Bennett, E.M., Frantzeskaki, N., Horcea-Milcu, A.I. and Lang, D.J. (2020), "Scaling the impact of sustainability initiatives: a typology of amplification processes", Urban Transformations, Vol. 2 No. 1, doi: 10.1186/s42854-020-00007-9.

Lankford, S.V., Buxton, B.P., Hetzler, R. and Little, J.R. (1995), "Response bias and wave analysis of mailed questionnaires in tourism impact assessments", Journal of Travel Research, Vol. 33 No. 4, pp. 8-13.

Lavie, D. (2006), "The competitive advantage of interconnected firms: an extension of the resourcebased view", Academy of Management Review, Vol. 31 No. 3, pp. 638-658. 
Lee, K.N. (1993), “Greed, scale mismatch, and learning”, Ecological Applications: a Publication of the Ecological Society of America, Vol. 3 No. 4, pp. 560-564.

Leisinger, K. (2015), "Business needs to embrace sustainability targets”, Nature, Vol. 528 No. 7581, p. 165.

Lewis, E.F., Hardy, M. and Snaith, B. (2013), "Estimating the effect of nonresponse bias in a survey of hospital organizations", Evaluation and the Health Professions, Vol. 36 No. 3, pp. 330-351.

Lin, H. (2012), "Cross-sector alliances for corporate social responsibility partner heterogeneity moderates environmental strategy outcomes", Journal of Business Ethics, Vol. 110 No. 2, pp. 219-229.

Lin, H. and Darnall, N. (2015), "Strategic alliance formation and structural configuration", Journal of Business Ethics, Vol. 127 No. 3, pp. 549-564.

Litwin, M.S. (1995), How to Measure Survey Reliability and Validity, Sage Publications, Thousand Oaks, CA.

Lizama-Pérez, F., Piñar-Álvarez, M., Ortega-Argueta, A., Mesa-Jurado, M.A., Sandoval-Caraveo, M. and Carrera-Hernández, A. (2018), "Implementation and performance of agenda 21 for local governments in Mexico", Regions and Cohesion, Vol. 8 No. 3, pp. 15-44.

Lotia, N. and Hardy, C. (2008), "Critical perspectives on collaboration", in Cropper, S., Huxham, C., Ebers, M. and Ring, P.S. (Eds), The Oxford Handbook of Inter-Organizational Relations, Oxford University Press, Oxford, pp. 203-230.

Loza, J. (2004), "Business-community partnerships: the case for community organization capacity building", Journal of Business Ethics, Vol. 53 No. 3, pp. 297-311.

MacDonald, A., Clarke, A., Huang, L. and Seitanidi, M.M. (2019), "Multi-stakeholder partnerships for sustainability: a resource-based view of partner implementation structure to outcomes", Sustainability, Vol. 11 No. 3, p. 557.

MacDonald, A., Clarke, A., Huang, L., Roseland, M. and Seitanidi, M.M. (2018), "Cross-Sector partnerships (SDG \#17) as a means of achieving sustainable communities and cities (SDG \#11)", in Leal Filho, W. (Ed.), Handbook of Sustainability Science and Research, Springer Publishing Company, New York, NY.

Margerum, R.D. and Robinson, C.J. (2015), "Collaborative partnerships and the challenges for sustainable water management", Current Opinion in Environmental Sustainability, Vol. 12, pp. 53-58.

Mintzberg, H. (2015), Rebalancing Society: Radical Renewal beyond Left, Right, and Center, BerretKoehler, Oakland, CA.

Moallemi, E.A., Malekpour, S., Hadjikakou, M., Raven, R., Szetey, K., Moghadam, M.M., Bandari, R., Lester, R. and Bryan, B.A. (2019), "Local agenda 2030 for sustainable development", The Lancet Planetary Health, Vol. 3 No. 6, pp. e240-e241.

Montiel, I., Gallo, P.J. and Antolin-Lopez, R. (2020), "What on earth should managers learn about corporate sustainability? A threshold concept approach", Journal of Business Ethics, Vol. 162 No. 4, pp. 857-880.

OECD (2013), OECD Guidelines on Measuring Subjective Well-Being, No. 60521, OECD Publishing, Paris, doi: 10.1787/9789264191655-en.

Ordonez-Ponce, E. and Clarke, A. (2020), "Sustainability cross-sector partnerships: the strategic role of organizational structures", Corporate Social Responsibility and Environmental Management, Vol. 27 No. 5, pp. 2122-2134.

Ordonez-Ponce, E. and Khare, A. (2020), "GRI 300 as a measurement tool for the united nations sustainable development goals: assessing the impact of car makers on sustainability", Journal of Environmental Planning and Management, Vol. 64 No. 1, pp. 47-75.

Osborn, D., Cutter, A. and Ullah, F. (2015), "Universal sustainable development goals. understanding the transformational challenge for developed countries", Stakeholder Forum.

Owen, A.L. and Videras, J. (2008), "Trust, cooperation, and implementation of sustainability programs: the case of local agenda 21", Ecological Economics, Vol. 68 Nos 1/2, pp. 259-272. 
SAMPJ

12,6

Pedersen, C.S. (2018), "The UN sustainable development goals (SDGs) are a great gift to business!", Procedia CIRP, presented at the 25th CIRP Life Cycle Engineering (LCE) Conference, Elsevier B.V., Copenhagen, pp. 21-24.

Penrose, E.T. (1959), "The theory of the growth of the firm”, Wiley, New York, NY, available at: http://books2. scholarsportal.info/viewdoc.html?id=/ebooks/ebooks0/oxford/2010-09-30/9780199573844

Peterson, G., Allen, C.R. and Holling, C.S. (1998), "Ecological resilience, biodiversity, and scale", Ecosystems, Vol. 1 No. 1, pp. 6-18.

Rerup, C. (2009), "Attentional triangulation: learning from unexpected rare crises", Organization Science, Vol. 20 No. 5, pp. 876-893.

Rittel, H.W.J. and Webber, M.M. (1973), "Dilemmas in a general theory of planning”, Policy Sciences, Vol. 4 No. 2, pp. 155-169.

Rok, A. and Kuhn, S. (2012), Local Sustainability 2012. Taking Stock and Moving Forward. Global Review, ICLEI - Local Governments for Sustainability, Bonn, pp. 1-87.

Rosales, J. (2008), "Economic growth, climate change, biodiversity loss: distributive justice for the global North and South", Conservation Biology, Vol. 22 No. 6, pp. 1409-1417.

Rosati, F. and Faria, L.G.D. (2019), "Business contribution to the sustainable development agenda: organizational factors related to early adoption of SDG reporting", Corporate Social Responsibility and Environmental Management, Vol. 26 No. 3, pp. 588-597.

Roseland, M. and Spiliotopoulou, M. (2016), "Converging urban agendas: toward healthy and sustainable communities", Social Sciences, Vol. 5 No. 3, p. 28.

Sachs, J.D. (2012), "From millennium development goals to sustainable development goals", The Lancet, Vol. 379 No. 9832, pp. 2206-2011.

Sachs, J.D., Schmidt-Traub, G., Kroll, C., Lafortune, G., Fuller, G. and Woelm, F. (2020), “The sustainable development goals and COVID-19. Sustainable development report 2020", Cambridge University Press, available at: https://dashboards.sdgindex.org/

Salvia, A.L., Leal Filho, W., Brandli, L.L. and Griebeler, J.S. (2019), "Assessing research trends related to sustainable development goals: local and global issues", Journal of Cleaner Production, Vol. 208, pp. 841-849.

Scheyvens, R., Banks, G. and Hughes, E. (2016), "The private sector and the SDGs: the need to move beyond “business as usual”', Sustainable Development, Vol. 24 No. 6, pp. 371-382.

Schmidt-Traub, G., Kroll, C., Teksoz, K., Durand-Delacre, D. and Sachs, J.D. (2017), "National baselines for the sustainable development goals assessed in the SDG index and dashboards", Nature Geoscience, Vol. 10 No. 8, pp. 547-555.

Schwartz, N. and Schuman, H. (1997), "Political knowledge, attribution and inferred interest in politics", International Journal of Public Opinion Research, Vol. 9 No. 2, pp. 191-195.

Secretaría Barcelona+Sostenible (2021), "Agenda 21 de Barcelona”, Barcelona + Sostenible, available at: www.sostenibilitatbcn.cat/index.php/castella (accessed 12 February 2016).

Seitanidi, M.M. and Crane, A. (2009), "Implementing CSR through partnerships: understanding the selection, design and institutionalisation of nonprofit-business partnerships", Journal of Business Ethics, Vol. 85, pp. 413-429.

Selsky, J.W. and Parker, B. (2005), "Cross-sector partnerships to address social issues: challenges to theory and practice", Journal of Management, Vol. 31 No. 6, pp. 849-873.

Shrivastava, P. (2018), "Business not-as-usual to achieve SDGs under climate change", in McIntyre, J.R., Ivanaj, S. and Ivanaj, V. (Eds), CSR and Climate Change Implications for Multinational Enterprises. New Horizons in International Business Series, Edward Elgar Publishing, Inc., Cheltenham, pp. 21-36.

Siltaoja, M.E. and Onkila, T.J. (2013), "Business in society or business and society: the construction of business-society relations in responsibility reports from a critical discursive perspective", Business Ethics: A European Review, Vol. 22 No. 4, pp. 357-373. 
Smith, T.W. (2010), "Surveying across nations and cultures", in Marsden, P.V. and Wright, J.D. (Eds), Handbook of Survey Research, 2nd ed., Emerald Group Publishing Limited, Bingley, pp. 733-763.

Spaiser, V., Ranganathan, S., Swain, R.B. and Sumpter, D. (2017), "The sustainable development oxymoron: quantifying and modelling the incompatibility of sustainable development goals", International Journal of Sustainable Development and World Ecology, Vol. 24 No. 6, pp. 457-470.

Spangenberg, J.H. (2017), "Hot air or comprehensive progress? A critical assessment of the SDGs", Sustainable Development, Vol. 25 No. 4, pp. 311-321.

Steffen, W., Richardson, K., Rockström, J., Cornell, S.E., Fetzer, I., Bennett, E.M., Biggs, R., Carpenter, S.R., De Vries, W., De Wit, C.A. and Folke, C. (2015), "Planetary boundaries: guiding human development on a changing planet", Science, Vol. 347 No. 6223, p. 1259855.

Steffen, W., Rockström, J. and Costanza, R. (2011), "How defining planetary boundaries can transform our approach to growth", The Solutions Journal, Vol. 2 No. 3.

Sudman, S., Bradburn, N.M. and Schwartz, N. (1996), Thinking about Answers: The Application of Cognitive Processes to Survey Methodology, Jossey-Bass Inc., San Francisco, CA.

Sullivan, K., Thomas, S. and Rosano, M. (2018), "Using industrial ecology and strategic management concepts to pursue the sustainable development goals", Journal of Cleaner Production, Vol. 174, pp. 237-246.

Sun, X., Clarke, A. and MacDonald, A. (2020), "Implementing community sustainability plans through partnership: examining the relationship between partnership structural features and climate change mitigation outcomes", Sustainability, Vol. 12 No. 15, p. 6172.

Swain, R.B. (2018), "A critical analysis of the sustainable development goals", in Leal Filho, W. (Ed.), Handbook of Sustainability Science and Research, Springer International Publishing, pp. 341-356.

Tourangeau, R. and Yan, T. (2007), "Sensitive questions in surveys", Psychological Bulletin, Vol. 133 No. 5, pp. 859-883.

UN-DESA (2015), “Agenda 21”, Sustainable Development Knowledge Platform, available at: https:// sustainabledevelopment.un.org/outcomedocuments/agenda21

United Nations Development Programme (2020), "Sustainable development goals", Sustainable Development Goals, available at: www.undp.org/content/undp/en/home/sustainable-development-goals.html

United Nations Habitat (2016), New Urban Agenda, UN Habitat, Quito, Ecuador.

United Nations (1992), “Agenda 21", United Nations Conference on Environment and Development (UNCED), Rio de Janeiro.

United Nations (2015a), "Draft outcome document of the united nations summit for the adoption of the post-2015 development agenda”, No. A/69/L.85, United Nations, available at: www.un.org/ga/ search/view_doc.asp?symbol=A/69/L.85\&Lang=E

United Nations (2015b), "Paris agreement", United Nations, Paris, available at: http://unfccc.int/files/ essential_background/convention/application/pdf/english_paris_agreement.pdf

United Nations (2019), "Sustainable development goals progress chart 2019", available at: https:// unstats.un.org/sdgs/report/2019/progress-chart.pdf

van Tulder, R. and Lucht, L. (2019), "Reversing materiality: from a reactive matrix to a proactive SDG agenda", in Bocken, N., Ritala, P., Albareda, L. and Verburg, R. (Eds), Innovation for Sustainability. Business Transformations towards a Better World, Palgrave Macmillan, Cham, doi: 10.1007/978-3-319-97385-2_15.

van Tulder, R., Seitanidi, M.M., Crane, A. and Brammer, S. (2016), "Enhancing the impact of crosssector partnerships. Four impact loops for channeling partnership studies", Journal of Business Ethics, Vol. 135 No. 1, pp. 1-17.

Verboven, H. and Vanherck, L. (2016), "Sustainability management of SMEs and the UN sustainable development goals", Uwf Umweltwirtschaftsforum, Vol. 24 Nos 2/3, pp. 165-178.

Ville de Montréal (2016), "Sustainable Montréal. Together for a sustainable metropolis", available at: http://ville. montreal.qc.ca/pls/portal/docs/page/d_durable_en/media/documents/plan_de_dd_en_lr.pdf. 
SAMPJ

12,6

1266

Ville de Montréal (2021), "Background on the approach", Sustainable Development, available at: http:// ville.montreal.qc.ca/portal/page?_pageid=7137,114541572\&_dad=portal\&_schema=PORTAL

Vurro, C., Dacin, M.T. and Perrini, F. (2010), "Institutional antecedents of partnering for social change: how institutional logics shape cross-sector partnerships", Journal of Business Ethics, Vol. 94, pp. 39-53.

Waddock, S.A. (1989), "Understanding social partnerships. An evolutionary model of partnership organizations", Administration and Society, Vol. 21 No. 1, pp. 78-100.

Waddock, S.A. (1991), "A typology of social partnership organizations”, Administration and Society, Vol. 22 No. 4, pp. 480-515.

Wassmer, U., Pain, G. and Paquin, R. (2017), “Taking environmental partnerships seriously”, Business Horizons, Vol. 60 No. 1, pp. 135-142.

Yin, R.K. (2014), Case Study Research: Design and Methods, Sage Publications, Thousand Oaks, CA.

Corresponding author

Eduardo Ordonez-Ponce can be contacted at: eduardo.ordonez@athabascau.ca 
Appendix 1

Sustainable development goals

\begin{tabular}{|c|c|c|}
\hline Capital & Drivers/outcomes & \\
\hline Sustainability & $\begin{array}{l}\text { S1: Contributing positively to the plan's sustainability goals } \\
\text { S2: Contributing positively to environmental challenges } \\
\text { S3: Contributing positively to social challenges } \\
\text { S4: Contributing positively to economic challenges }\end{array}$ & 1267 \\
\hline Human & $\begin{array}{l}\text { S5: Contributing positively to the sustainability of the community } \\
\text { H6: Gaining knowledge/learning } \\
\text { H7: Gaining expertise } \\
\text { H8: Sharing own experience } \\
\text { H9: Improving competencies }\end{array}$ & \\
\hline Organizational & $\begin{array}{l}\text { O10: Improving the organization's sustainability } \\
\text { O11: Developing innovation capacity } \\
\text { O12: Building new relationships } \\
\text { O13: Improving reputation } \\
\text { O14: Gaining legitimacy } \\
\text { O15: Becoming more influential } \\
\text { O16: Having access to new markets } \\
\text { O17: Marketing opportunities } \\
\text { O18: Networking } \\
\text { O19: Collaborating with others } \\
\text { O20: Engaging with the community } \\
\text { O21: Improving relationships with authorities } \\
\text { O22: Improving relationships with NGOs }\end{array}$ & \\
\hline Financial & $\begin{array}{l}\text { F23: Improving financial performance } \\
\text { F24: Reducing costs } \\
\text { F25: Funding opportunities } \\
\text { F26: Developing new products/services } \\
\text { F27: Making new businesses } \\
\text { F28: Attracting new investors } \\
\text { F29: Increasing financial resources }\end{array}$ & (1) \\
\hline Physical & $\begin{array}{l}\text { P30: Increasing physical resources } \\
\text { P31: Improving processes }\end{array}$ & $\begin{array}{r}\text { List of business } \\
\text { drivers and outcomes }\end{array}$ \\
\hline
\end{tabular}

\section{Appendix 2}

\begin{tabular}{|c|c|c|c|c|}
\hline Cronbach's $\alpha$ & Items & Drivers & Outcomes & \\
\hline Sustainability capital & 5 & 0.77 & 0.92 & \\
\hline Human capital & 4 & 0.90 & 0.90 & Table A \\
\hline Organizational capital & 13 & 0.90 & 0.93 & Cronbach's $\alpha$ results \\
\hline Financial capital & 7 & 0.93 & 0.95 & for drivers and \\
\hline Physical capital & 2 & 0.87 & 0.85 & outcomes variables \\
\hline
\end{tabular}

For instructions on how to order reprints of this article, please visit our website: www.emeraldgrouppublishing.com/licensing/reprints.htm Or contact us for further details: permissions@emeraldinsight.com 